\title{
EL CONDE DE COMMINGE: FORTUNA LITERARIA DE UN MITO DIECIOCHESCO EN FRANCIA Y EN ESPAÑA
}

\author{
MARÍa Jesús García Garrosa
}

Universidad de Valladolid

Hay personajes literarios cuya vida define toda una época, y amores trágicos convertidos en símbolos de un determinado período de nuestra historia cultural. A esa categoría pertenece sin ninguna duda el Conde de Comminge. Menos conocido que Pamela, Héloïse, o Émile, es sin embargo un personaje emblemático de la historia literaria del siglo de las luces, y sus amores desgraciados con Adélaïde de Lussan fueron la versión dieciochesca del mito eterno de la trágica pasión amorosa.

La historia del Conde de Cominges tuvo una vida literaria de más de un siglo, asistió a los cambios de gusto y la sucesión de tendencias. Fue lectura novelesca, poema exaltado y pieza teatral; pasó de uno a otro con fluidez, adaptándose a las exigencias de cada género. Viajó de Francia a España, conoció censuras y prohibiciones; llegó aquí tarde, y en ocasiones deformado; pero precisamente por ello es puente de paso obligado para entender el fenómeno complejo de la recepción y la asimilación culturales. La historia del Conde de Cominges es, en suma, un hecho literario multiforme que, más allá de su importancia y valores intrínsecos, se presenta como el ejemplo perfecto para analizar el diferente tratamiento que distintos países, géneros y períodos dieron a un mismo asunto literario. 


\section{LOS ORIGENES}

Claudine-Alexandrine de Guérin, Marquesa de Tencin, personaje destacado del París de la Regencia, y cuya vida tuvo mucho de aventura novelesca, sorprendió a todos cuando publicó en $1735^{1}$ una novela que nada temía que ver con su talante libertino, las Mémoires du Comte de Comminge ${ }^{2}$. La novela, cuya autoría fue incluso puesta en duda, recreaba un mito eterno, pero con los ropajes propios del siglo XVIII: el de los amantes desgraciados, y lo hacía con la fuerza de una obra primera pero definitiva.

Las familias de Comminge y de Lussan son enemigas a causa de un viejo asunto de herencias. El odio de los padres se perpetúa en los hijos, pero el destino dispone que un nuevo sentimiento transforme sus vidas. El Conde de Comminge conoce en un balneario a su prima Adélaïde de Lussan, y surge entre ellos un amor que hubiera podido poner fin a las desavenencias familiares. Pero el odio de Comminge padre es demasiado fuerte, y el amor se crece ante el obstáculo hasta convertirse en pasión irrenunciable. Comminge quema los documentos que hacían a los Lussan legítimos dueños de la herencia, y la furia del padre lo encierra en una torre del castillo. Adélaïde, apasionada también, pero dispuesta a sacrificar su felicidad a la salvación de su amante, elige como esposo al más aborrecible de los hombres. Comminge queda libre, desesperado y ciego en su pasión. Consigue introducirse en casa de Adélaïde, inclinarse a sus pies en un último adiós impuesto por ella, y el esposo celoso los sorprende. Bénavidès es herido, Comminge huye. Poco tiempo después, le anuncian que Adélaïde ha muerto. La desesperación se traduce ahora en un dolor que busca la soledad para expresarse, y Comminge hace sus votos en una abadía de la Trapa. Pero Adélaïde no ha muerto; vivió dos años encerrada en otra torre de otro castillo por orden de su esposo. Ahora, viuda, vaga en busca de un lugar donde esconder su dolor. El destino la pone en el camino de la abadía trapense, descubre allí a su amado, y vive, bajo el hábito de un monje, tres años al lado del atormentado Comminge. La campana anuncia la agonía de un religioso. Y Adélaïde, en su lecho de cenizas, ruega al hombre al que tanto ha amado que se cure de su pasión y busque en Dios la serenidad y el perdón.

1 Ese mismo año, Nivelle de la Chausée daba a la escena su primera «comédie larmoyante», Le préjugé à la mode. Por diferentes caminos, ambos autores están proponiendo una fórmula innovadora: el sentimiento, o si se quiere, su traducción literaria, el sentimentalismo, hijo de las doctrinas filosóficas de Locke.

${ }^{2}$ Mémoires du Comte de Comminge, La Haye, J. NeaulnE, 1735, 184 págs. 
Las Mémoires du Comte de Comminge son una novela del sentimiento y el dolor, el dolor que es explaya y se complace en su total disfrute ( J'imaginais presque un plaisir à me rendre encore plus misérable que je ne l'étais.» [pág. $72^{3} \mathrm{j}$ ), que se acentúa en cada página y vuelve siempre sobre sí mismo. Con estas palabras inicia y concluye Comminge el relato de su vida:

Je n'ai d'autre dessein en écrivant les Mémoires de ma vie que de rappeler les plus petites circonstances de mes malheurs, et de les graver encore s'il est possible, plus profondement dans mon souvenir (pág. 21) (...) j'y suis [en una ermita] despuis plusieurs années, n'ayant d'autre occupation que celle de pleurer ce que j'ai perdu (pág. 94).

Hay algo de plenamente dieciochesco en esta actitud: la exigencia ética y estética de expresar el sentimiento, de no contenerlo y dejarlo correr libremente regado de lágrimas. Es la suprema manifestación de una alma sensible: «(...) mes larmes coulaient et j'y trouvais une espèce de douceur.» (pág. 42).

Sin embargo, algo sorprende en este planteamiento. Los héroes sensibles del XVIII «no sufren», no hasta ese punto, ni, sobre todo, con esa intensidad. Y no sufren porque «no aman». Los héroes sensibles del XVIII, salvo contadas excepciones, no saben lo que es la pasión amorosa. Se enamoran, sí, pero siempre de la virtud del otro. Y por ese camino, no se puede llegar ni a la pasión ni al dolor desgarrado. Comminge no se enamora de la virtud de Adélaïde. Se dice de ella que es bella, modesta, dulce, franca. Pero su virtud no se menciona como la suma cualidad que esperaríamos en este siglo. Y de este amor del otro, $y$ no de la virtud del otro, sí puede llegarse a la pasión, y al dolor.

La literatura del XVIII crearía personajes virtuosos y sensibles que debían enfrentarse a una dificultad para realizar su amor. Ese obstáculo era casi siempre la oposición paterna al matrimonio, argumentando la diferencia de clase. $\mathrm{E}$ (la) noble se enamoraba de la plebeya (o) y el orden social vigente impedía semejante desajuste. El amante desfavorecido debía demostrar que su virtud era tan digna como un título nobiliario y la diferencia quedaba saldada. Pero había una solución más fácil, y de resultados literarios más expresivos: una milagrosa anagnórisis final descubría al amante plebeyo un oculto apellido aristocrático. Lograda la igualdad, el desenlace era inevitablemente feliz. Un matiz final: la

3 Cito por la edición moderna de la obra, realizada en París, Éditions Desjonquères, 1985. Introducción de MiCHEL DELON. En esta y en todas las citas mantendré siempre la ortografía, acentuación y puntuación de los originales a los que remito. 
dificultad no era tan insalvable como para obligar a los amantes a renunciar a su amor. La virtud siempre vencía. Pero leyendo entre líneas, comprendemos que se trata, al fin, de una derrota: la del individuo frente a la sociedad, que impone sus normas colectivas y exige que el comportamiento individual se ajuste a ellas.

Comminge y Adélaïde no son amantes de esta clase. No existe entre ellos una diferencia de condición que se eleve como un obstáculo, ni una virtud que haya que poner a prueba para ser dignos de la bendición de la sociedad. Existen dos pasiones: el odio y el amor, dos fuerzas enfrentadas: el individuo y sus sentimientos, y la sociedad y sus normas.

El padre tiránico que se opone con todo el derecho que le da la ley a la felicidad de sus hijos, tuvo amplia representación en la literatura de este siglo. Comminge padre pertenece a esa estirpe. Pero los padres de los dramas y novelas de esta época, sensibles al fin, acaban siempre cediendo ante la fuerza irresistible de las lágrimas, ayudados por ese azar que elevaba en el último momento el rango social del pretendiente plebeyo.

Comminge padre, con su oposición inquebrantable al matrimonio de su hijo y Adélaïde, convierte automáticamente a la pareja en los personajes prototípicos de la creación literaria dieciochesca: los amantes que deben luchar por su felicidad. Pero hay algo más. La defensa de los valores aristocráticos ha sido sustituida por el odio. En consecuencia, los intereses sociales han dado paso a los individuales. Este cambio fundamental modifica sustancialmente los presupuestos dieciochescos de la novela. Ya no estamos ante unos personajes cuya virtud acaba por integrarlos en el orden moral y social. Comminge y Adélaïde son los amantes desgraciados, perseguidos, que oponen su pasión a esos códigos colectivos y pagan con el dolor y la muerte su enfrentamiento.

Toda una serie de matices nuevos acompañan este cambio de actitud: torres oscuras de castillos que sirven de prisión y anuncian decorados novelescos futuros; el deseo de rebelión frente a las normas que se oponen al ejercicio de la libertad (Comminge: «Et pourquoi nous assujettir (...) à la tyrannie de nos pères», pág. 41); una nítida conciencia del fatal destino (Adélaïde: «Je n'envisage que des malheurs», pág. 33); una pasión ciega que escapa al control de la razón (Comminge: «une fatalité dont il n'est pas le maître» pág. 35) y que conduce a un desenlace fatal; $y$, sobre todo, un dolor creciente que busca como único cobijo la soledad, y el recuerdo constante de la muerte en una abadía trapense:

L'assurance que j'avais par là que mes larmes ne seraient point troublées et que je passerais ma vie entière dans cet exercice, me donna 
quelque espèce de consolation. L'affreuse solitude, le silence qui regnait toujours dans cette maison, la tristesse de tous ceux qui m'environnaient me laissaient tout entier à cette douleur qui m'était devenue si chère. (pág. 87).

Todo esto, hay que reconocerlo, es muy poco dieciochesco. $\mathbf{M}^{\mathrm{me}}$ de Tencin ha escrito una historia que se aparta en muchos de sus elementos de los caminos trazados por la moral y la estética dominantes, ha dado vida a dos personajes cuya pasión les otorga un valor negado por este siglo: la individualidad. ¿Estamos ya ante actitudes románticas? $\mathrm{O}$, por ajustarse más a lo histórico -es el año 1735-, ¿Mme de Tencin ha escrito una obra prerromántica? La respuesta está en las últimas páginas de la novela.

Antes de morir, Adélaîde convoca a los trapenses y confiesa un sentimiento nuevo: el arrepentimiento. Una sola frase parece devolver a esta amante descarriada al redil de las almas virtuosas: «il était comme moi la malheureuse victime d'une passion criminelle." (pág. 92). Víctima inocente de una pasión incontrolable, pero consciente al fin de su error, intenta arrastrar en su arrepentimiento al amante atormentado:

Si le compagnon de mes égarements gémit encore sous le poids du péché qu'il jette les yeux sur moi, qu'il consisdère ce qu'il a follement aimé, qu'il pense à ce moment redoutable où je touche et où il touchera bientôt; à ce jour où Dieu fera taire sa miséricorde pour n'écouter que sa justice. (pág. 92).

pero éste - recuérdese la frase que cierra la novela - muestra más intenciones de llorar lo perdido y seguir recreándose en el dolor que de dar pruebas de un arrepentimiento que sólo estas palabras parecen sugerir: «Ma chère Adélaïde obtiendra de Dieu que ma pénitence soit salutaire.» (pág. 92).

Será justo, sin embargo, añadir una matización. Toda la novela está escrita en primera persona, y de manera que la voz de la autora no se deja jamás oír. No hay juicios, ni condenas. Comminge tiene la primera y la última palabra. En las Mémoires sólo habla el sentimiento. Y aquí, precisamente, se producirá el principal cambio que introducirá la versión teatral de esta historia. 
El sentimiento y la exaltación de las virtudes burguesas marcaban las pautas en la vida escénica francesa en los años sesenta del siglo XVIII, cuando algunos autores dramáticos emperazon a utilizar nuevos elementos que aumentaran la efectividad de la representación. Puesto que se trataba de «sentir», y cuanto más, mejor, a las lágrimas y las escenas emotivas se fueron añadiendo un sombrío patetismo, ambientes tétricos, decorados lúgubres, sentimientos desgarradores. En dos palabras: al sentimentalismo se le superpuso el terror.

Uno de esos dramaturgos era François-Thomas Baculard d'Arnaud, quien, zanjando la avivada polémica sobre el parentesco del género dramático sentimental con la comedia y la tragedia, tenía muy claro, en 1764 , que el drama, el drama dieciochesco, era hijo directo de la tragedia clásica. Y encontró en la novela de $\mathbf{M}^{\text {me }}$ de Tencin el argumento ideal para demostrarlo:

Si la Pitié et la Terreur sont les deux grands ressorts que doive employer le Théâtre, jamais Fable ne fut plus susceptible de ces deux mouvements énergiques, que le sujet DU COMTE DE COMMINGE 4 .

Con Les Amants malhereux ${ }^{5}$ la historia de Comminge y Adélaïde se convertía en drama en $1764^{6}$.

Baculard da muestras de un gran instinto teatral al elegir sólo la última parte de la novela para construir su obra. La elección tenía sus ventajas, estéticas y morales. Por un lado, presentando a los amantes en su retiro de la Trapa, concentraba la acción en un único lugar y, aunque de manera un tanto forzada, podía respetar también la unidad de tiempo que imponían las reglas del drama ${ }^{7}$. Además, esta parte final, con los protagonistas bajo un mismo techo entregados

4 «Discours Préliminaire» a la primera edición de Les Amans malheureux, cit. en nota siguiente, pág. 5.

${ }^{5}$ Les Amans Malheureux, ou Le Comte de Comminge, drame en trois actes et en vers. Précédé d'un Discours Préliminaire et suivi des Mémoires du Comte de Comminge, La Haye-Paris, L'Esclapart. 1764. Citaré por esta edición.

6 Como los otros dramas del autor, tardaría bastantes años en ser puesto en escena. Se estrenó en Paŕs el 14 de mayo de 1790.

7 Empleo esta palabra con la acepción que dio Diderot al término «drame» al inaugurar este género en 1757 con Le Fils naturel: pieza dramática situada entre la tragedia y la comedia que pretende emocionar al espectador y moverle a imitar la virtud. 
al dolor de una pasión no consumada, ofrecía la posibilidad de un análisis psicológico más detenido y profundo que el llevado a cabo por $\mathbf{M}^{\mathrm{me}}$ de Tencin. Por otro lado, era sólo en esos últimos momento de la novela en donde aparecía la idea de arrepentimiento. En suma, el argumento de la Marquesa de Tencin dio a Baculard d'Arnaud la ocasión de crear una pieza teatral con elevadas dosis de patetismo, que analizaba los desgarros de la pasión amorosa y presentaba sus fatales consecuencias. Conmover y enseñar el camino de la virtud, los dos objetivos básicos del drama.

El ambiente de una abadía trapenese no lo hubiera creado mejor ni el propio dramaturgo. Claro que él lo convirtió en decorado teatral en el que no quedaba suelto un detalle: un subterráneo largo y profundo iluminado con una sola lámpara, una gran cruz a cuyo pie se amontonan las calaveras, una fosa que a lo largo de la acción irá cavando el protagonista, aquí y allá tumbas de monjes e inscripciones que recuerdan que es un lugar de muerte, las cuerdas de una campana que tañerá durante toda la última escena, monjes encapuchados que repiten letanías de muerte, infierno y eternidad.

En este sombrio decorado, Comminge se debate entre su pasión y los sagrados votos pronunciados; Adélaïde, convertida en el hermano Euthime, vaga como una sombra sin pronunciar una palabra hasta la famosa confesión de la última escena; el Abad se afana inútilmente en arrancarle a Comminge su ciega pasión; d'Orvigny, el cuñado y amante en silencio de Adélaïde, asiste impotente a la explosión de sentimiento de los protagonistas.

Antes de cualquier análisis, convendrá dejar claro un punto esencial: a Baculard le mueve una poderosa intención moral. Consciente de que la última escena, con la extensa confesión de una Adélaiide agonizante, puede parecer demasiado larga, escribe una larga nota al final del texto justificándola: «il fallait que cette Scène fût un tableau pathétique de morale ${ }^{8}$; c'est pour cette Scène que la Piece a été faite.» (pág. 91). La escena, precisa el autor, no es más que el desarrollo del carácter de una mujer apasionada. Y la pasión, a la que el dramaturgo considera culpable de las desgracias y hasta los crímenes, es lo que quiere combatir. Dicho de otra manera. Baculard, imbuído del carácter moralizador del siglo, comprende muy bien que la novela de $\mathbf{M}^{\text {me }}$ de Tencin no se ajusta a esas exigencias. Con un leve, pero insuficiente, arrepentimiento final, las $M e^{\prime}$ moires exaltan la más poderosa imagen de los amantes que se rebelan y prefieren el dolor a la virtud.

${ }^{8}$ El subrayado es mío. 
Para hacer una obra moralizante, Baculard d'Amaud debe modificar algunos elementos de la historia, pero, sobre todo, tiene que dar rasgos nuevos al carácter de los personajes ${ }^{9}$.

Comminge será ahora el hermano Arsène, un hombre desgarrado por el dolor y consumido por el fuego de una pasión que no puede controlar. En vano se empeña en llenarse los ojos y el alma de imágenes de la muerte que le recuerden el juicio divino; en vano el padre Abad le ofrece los consuelos de la religión. Su corazón es un campo de batalla en que el luchan el amor y el arrepentimiento: «Comminge existe encore, et brûle au coeur d'Arsène!/L'homme, plus que jamais, s'elève et me combat.» (act. I, esc. 1). Porque este Comminge sí se arrepiente, sí expresa con suficiente claridad e insistencia una amarga conciencia de culpa: «J'etois à cet excès par le crime égaré.» «Elle [la religión] fait dans mon coeur descendre le remord», «Elle m'a pénétré du repentir sincère...» $(I, 1)$. Su terrible combate interior va en aumento. Al final del primer acto le dicen que Adélaïde vive. Es el infierno: «L'Enfer est dans mon coeur.» (I,7). Y en la magnífica escena que abre el acto segundo, Comminge, enloquecido, blasfema, reniega de sus votos, reclama su libertad para seguir amando: «L'aveugle humanité,/ Ne doit former des voeux que pour la liberté.» Pero no escribe $\mathbf{M}^{\text {me }}$ de Tencin, sino el moralista Baculard d'Arnaud. El grito de libertad es apagado, y de ello se encarga el Abad.

Para el Comminge de la novela la muerte era el descanso, el fin del dolor. Para el hermano Arsène la muerte debe ser la advertencia del fin y del juicio de Dios. El padre Abad se lo recuerda insistentemente, presentándole primero la imagen de un Dios compasivo y misericordioso, que perdona al pecador arrepentido (I,2), y amenazando luego con un juicio implacable (II,4).

Por si la voz de la religión y su representante oficial no surten efecto, Baculard recurre además a la de la propia Adélaïde, que en su lecho de muerte $(I I I, 6)$ no cesa de entonar un lúgubre canto de arrepentimiento: «une femme coupable,/ Et la plus criminelle, et la plus misérable» en el que vuelven una y otra vez los adjetivos culpabilizadores: «un fol amour», «cette fatale ivresse»,

9 Baculard confiesa la razón y la índole de estos cambios en el «Discours Préliminaire»: «On nous le fait voir [al Conde] venant à la Trappe avec beaucoup d'indifférence pour la Religion, rempli de sa seule douleur; j'ai pensé qu'en lui donnant de la piété, je varierois ce caractere, je le rendois plus naturel, plus enflamé, plus déchiré par ces orages de passion qui au theâtre produissent presque toujours des effets sûrs de plaire.» En cuanto a Adélaîde: «C'est à ce dernier personnage que j'ai attaché toute la fureur de l'amour. Ce n'est qu'au moment de sa mort qu'il reconnoît ses erreurs, et ce passage subit de sa passion à la ferveur la plus vive, au repentir le plus amer, doit selon moi flatter et remuer le spectateur.» (págs. 13-15). Obsérvese su insistencia en los aspectos puramente teatrales $y$ los efectos que quiere conseguir. 
«ma criminelle ardeur», «une amour criminelle» «mon sacrilège hommage». Y la llamada al arrepentimiento, a la conversión, que en $\mathbf{M}^{\mathrm{me}}$ de Tencin quedaba condensada en tres líneas, se alarga ahora en docenas de versos insistentes: «Mais laisse-moi t'ouvrir le chemin du remord. (...) Remplis-toi de Dieu seul... à sa voix obéis.../ Et que ton repentir de ma mort soit le prix!»

En las Mémoires du Comte de Comminge sólo hablaba la voz del sentimiento. En Les Amants malheureux la última palabra la tiene el dramaturgo, para avisar y condenar: «Gran Dieu, qu'est-ce que l'homme aux passions livré!....» ${ }^{10}$

\section{LA VUELTA A LOS ORÍGENES}

Mientras Baculard d'Arnaud mostraba las fatales consecuencias de la pasión, un joven poeta, novelista y dramaturgo, Claude-Joseph Dorat, plasmaba en un largo poema su particular visión de los amores de Comminge y Adélaïde: la Lettre du Comte de Comminge à sa mère ${ }^{11}$, publicada también en 1764, y que, sin embargo, está más cerca de la novela que del drama.

Algo vuelve a cambiar en esta versión que la acerca a los orígenes. No hay más voz que la de Comminge. Ninguna injerencia, ningún juicio ni lección moral. Y también aquí el dolor como único sentimiento, como única forma de vida. Pero han pasado casi treinta años desde las Mémoires y Dorat habla de otra forma de dolor.

Comminge escribe ahora una larga carta a su madre. Hace veinte años que murió Adélaïde y él sólo vive para esperar su propia muerte. El poema narra los acontecimientos ya sabidos: la oposición paterna, el matrimonio de Adélaïde, la búsqueda de un lugar donde esconder el dolor, la vida atormentada en el monasterio, la confesión de la amada antes de morir... Pero todo avanza rápido. No es eso lo que Comminge quiere transmitir a su madre, porque tampoco él y Adélaïde son los mismos personajes que presentaron la novela y el drama.

10 Ya antes el propio Abad había sentenciado: «Voilà des passions les effets déplorables.» (II,3) E incluso Adélaïde advierte: «(...) vous voyez l'effet des passions,/ Le jour affreux qui naît de leurs illusions!» (III,6). Me parece interesante señalar a este respecto que el título del drama contiene en sí toda la enseñanza moral que se quiere transmitir. Para Baculard d'Arnaud, Comminge y Adélaïde no son los amantes desgraciados por la oposición a la consumación de su amor, sino, muy al contrario, por ser víctimas de la pasión y de sus «efectos deplorables».

11 Lettre du Comte de Comminge à sa mère, suivie d'une lettre de Philomèle à Progné, París, S. JORRY, 176468 págs. 
No hay sentimiento de culpa, ni, por tanto, remordimientos, y menos aún arrepentimiento. Ni siquiera la pasión parece tan feroz y desgarradora. Amor, aquí, es sinónimo de paz. La paz que el odio paterno arrancó a los amantes y que Comminge fue a buscar a la soledad de la Trapa, que encontró al fin, que Adélaïde al morir le arrebató de nuevo y que ella misma le promete más allá de la muerte. Por eso el poema, más profundo, más intenso sin duda que la novela en los sentimientos, resulta a la vez más sereno en la descripción del dolor y del amor imposible, a pesar de que Dorat se recrea en las imágenes fúnebres, los adjetivos sombríos y los ríos de lágrimas.

Adélaïde no es la mujer atormentada por el sentimiento de culpa del drama. Es la amante que no puede resistir la llamada del amor, que se encierra en la soledad del monasterio porque la sola contemplación callada del amante y la certeza de ser amada la hacen feliz ( $\ll \mathrm{J}$ 'aimois; et près de toi $(. ..) / \mathrm{Je}$ m'énivrois encore du plaisir d'être aimée./ $\mathrm{Va}$, je n'eusse jamais voulu d'autre bonheur.» (pág. 84) ${ }^{12}$, y que siente que al fin él ha encontrado la serenidad para el espíritu y el consuelo a su dolor. Por eso sus palabras antes de morir no son una llamada al arrepentimiento ante el juicio de un Dios implacable, sino una petición de perdón por robarle de nuevo esa paz tan costosa. Sólo convertida en una sombra que Comminge persigue en los delirios del sueño, le invita a pensar en la muerte, «un passage et nous mène au bonheur» (pág. 89), un camino que le llevará directamente hasta ella, «la divinité, dont elle fut l'image» (pág. 89) que le espera desde el más allá.

Y el Comminge que escribe ahora en nada se parece al hermano Arsène luchando dramáticamente entre su pasión y sus votos. Ni siquiera es el eremita sombrío que habla en la novela, contemplando con delectación su propio sufrimiento ahogado en los límites de su corazón. El Comminge de este poema grita su dolor, lo arrastra en su recorrido frenético por una naturaleza sombría y fantasmagórica, persigue entre las sombras la sombra de su amada y la ve escaparse de entre sus dedos. Y ese dolor es, por encima de todo, el dolor de la muerte, más fuerte que el odio de su padre que le negó a su amada, más impenetrable que la torre del castillo en que fue encerrada, que le ha quitado todo, «Espoir, amour, bonheur, tout ce qui fut sacré.» (pág. 86) y que se resiste a llevarle a él.

Con la Lettre du Comte de Comminge à sa mère, la vida de Comminge y Adélaïde vuelve a ser una exaltación del amor y del individuo, pero en donde el dolor acaba al fin redimido por la muerte: «Que le trépas est doux après tant de malheurs!» (92).

12 Cito por la edición de París, Lepetit, 1793, que incluye también la novela y el drama. 


\section{LA Historia del CONDE DE COMMINGE EN ESPAÑA}

La historia del Conde de Comminge se convirtió en un clásico de la literatura sentimental francesa a partir de 1764. Desde esa fecha, y con sucesivas ediciones que llegan incluso hasta los inicios del siglo XX, se publican en un mismo volumen la novela, el drama y el poema, que forman ya un todo inseparable. Es la visión completa de un mito que empieza a cruzar fronteras.

En España, debió de conocerse muy pronto ${ }^{13}$, aunque las traducciones empezaron en fecha relativamente tardía y rodeadas todas ellas de circunstancias peculiares.

\section{LAS VERSIONES DRAMÁTICAS}

Fue una pieza de teatro la primera versión que se conoció en España. En 1791, se publicaba en Madrid Los amantes desgraciados o el Conde de Comin$g e^{14}$, traducción de Manuel Bellosartes del drama de Baculard d'Arnaud. A esta edición siguieron otras en $1792^{15}, 1820^{16}$ y $1836^{17}$, pero su fortuna en los tea-

13 Entre los libros franceses de la biblioteca de Olavide se encuentran precisamente las Mémoires du Comte de Comminge, de $\mathrm{M}^{\mathrm{me}}$ de Tencin, y Le comte de Comminges (sic), de Baculard d'Arnaud. Cf. Marcelin Defourneaux: Pablo de Olavide ou al'Afrancesado», París, P.U.F., 1959.

14 Los amantes desgraciados ó el Conde de Cominge, Drama en tres actos. Escrito en Francés por Mr. d'Arnaud, y traducido al Castellano por Don Manuel Bellosartes. Madrid, 1791. Se hallará en la Librería de Quiroga. 124 págs., una lámina.

15 Los amantes desgraciados o el conde de Cominge, Barcelona, Viuda Piferrer, 1792. Ejemplar no localizado, citado por FRANCISCO LAFARGA: Las traducciones españolas del teatro francés (1700-1835). I. Bibliografía de Impresos, Universidad de Barcelona, 1983, pág. 40.

16 Los amantes desgraciados ó el Conde de Cominge. Drama en tres actos. Escrito en Frances por Mr. d'Amaud y traducido al castellano por Don Manuel Bellosartes. Tercera Parte. Barcelona, Imprenta de José Torner, 1820, 30 págs. La traducción es idéntica a la de la edición de 1791; varian únicamente la grafía y la acentuación. Incluye, como aquélla, el extracto de las Memorias del Conde de Cominge.

17 El Conde de Comminge. Drama en tres actos: Escrito en Francés por Mr. d'Amaud, y traducido al castellano por Don Manuel Bellosartes. Ocupa las páginas [153]-228 de la Historia del Conde de Comminge, Barcelona, Librería de Don Manuel Saur, 1836. Traducción idéntica a la de 1791. 
tros no se correspondió con este éxito editorial. Parece que no llegó a representarse, y fue prohibida el 4 de junio de $1801^{18}$.

Los amantes desgraciados, drama escrito en endecasílabos pareados, es una traducción completamente fiel del texto original. La literalidad llega a veces al extremo de frases agramaticales en correcto castellano o a la presencia de reiterados galicismos. Sólo se permitió Bellosartes reducir en algunos momentos las ricas acotaciones del texto francés, pero sin que su versión pierda por ello nada de la teatralidad ni los muy logrados efectos escénicos de este drama patético y conmovedor.

Y puesto que todo es idéntico, los ¿espectadores? españoles recibieron con esta primera versión de la trágica historia de los amantes desgraciados, la misma visión moralizante: el aviso sobre las terribles consecuencias de la pasión amorosa que no frenan ni la razón ni la virtud. Es más, el último verso del Abad francés: «Grand Dieu, qu'est-ce que l'homme aux passions livré», da lugar a tres jugosos versos en boca del Abad español: «¿Porque al fin qué es el hombre, 6 Dios Piadoso,/ sino un caos de horror y confusiones,/ entregado al furor de sus pasiones?»

El hecho de que la vida de estos personajes llegara a España inicialmente reducida a su último episodio, obligó a los editores del drama a acompañarlo de un «Extracto de las Memorias del Conde de Cominge, que sirve à este Drama de explicacion y argumento» (págs. 3-13 en la edición de 1791), resumen muy fiel de la novela de $\mathbf{M}^{\text {me }}$ de Tencin que ponía al público español al corriente del inicio de los acontecimientos.

Esa historia, como hemos visto, tenía ya en la novela tres partes bien diferenciables: el amor que surge entre los protagonistas y la oposición del padre; las dificultades para consolidad su relación: encierro de Comminge en el castillo, matrimonio de Adélaïde, enfrentamiento entre Comminge y Benavides, y

${ }^{18}$ El 16-IX-1793, la Compañfa de Martínez representó en Madrid una pieza titulada Los amantes desgraciados, pero el reparto, en el que incluso figura un niño, no se corresponde en absoluto con el «Dramatis Personae» de nuestro drama. Otro tanto puede decirse de las dos representaciones (30-V-1797 y 23-XI-1799) que hizo en Madrid la Compañía de Ramos del «diálogo» de Los amantes desgraciados. Puede tratarse de una condensación de la última escena del drama, pero me parece improbable. Teniendo en cuenta que El Conde de Cominges, representado por la Compañía de Ramos el 24-I-1797 es la versión de Comella de la que luego hablaré, debemos concluir que la versión de Bellosartes no se representó nunca en España, al menos en Madrid. Cf. EMIlo Cortarelo: Isidoro Máiquez y el teatro de su tiempo, Madrid, Impr. de José Perales y Martínez, 1902, págs. 55, 576, 592 y 614 y ADA COE: Catálogo bibliográfico y crítico de las comedias anunciadas en los periodicos de Madrid desde 166/ hasta 1819, Baltimore, The John Hopkins Press, 1935, págs. 9-10. 
encarcelamiento de aquélla; y, por fin, su vida paralela en el monasterio de la Trapa, y la confesión y muerte de Adélaïde.

Esta estructura tripartita hacía posible la composición de tres piezas teatrales interrelacionadas, pero independientes, que tomaran como asunto esos tres episodios. Y eso precisamente es lo que sucedió en España, lo cual indica que, sin duda, aunque la novela de $\mathbf{M}^{\mathrm{me}}$ de Tencin tardara aún muchos años en traducirse, era ya conocida en España en la última década del siglo XVIII.

En 1797, como ya hemos visto, se daba una primera, y sin duda única, representación de El Conde de Cominges, título abreviado de la pieza de Comella Los amores del Conde de Cominges ${ }^{19}$.

La comedia dramatiza los primeros episodios de la relación entre Cominges y Adelaida de Lusan $^{20}$, desde su encuentro en el balneario a su separación tras la oposición paterna, pero salvo el nombre de los protagonistas y algunos pequeños detalles, sería dif́́cil reconocer en esta pieza la historia original de $\mathbf{M}^{\mathrm{me}}$ de Tencin. Comella, que según una de las ediciones, traduce una comedia italiana, empieza por incluir personajes que ni siquiera están sugeridos en la novela francesa: un conde despistado en cuya casa se aloja Cominges y cuya presencia sólo tiene explicación si se quiere provocar la hilaridad del espectador con sus despropósitos; una tal condesa Matilde, su hija, que airea su peculiar criterio sobre el amor y que sólo piensa en tener una corte de admiradores; y un caballero Ernesto al que no logro encontrar justificación en la comedia. Junto a ellos, el caballero de San Odón, personaje accidental en la novela, que aquí se convierte en un petimetre que abruma con sus chistes y su presencia a Adelaida, un conde de Cominges padre que poco tiene que ver con su enérgico homónimo francés. $Y$, sobre todo, unos Cominges y Adelaida que no son ni la sombra de sí mismos. Véase, como ejemplo, un fragmento del diálogo que mantienen estos desfigurados amantes:

19 La obra tuvo dos ediciones: Comedia Nueva Los amores del Conde de Cominges, Drama en cinco actos por Don Luciano Francisco Comella, [Barcelona], s. a., 24 págs., y Los amores del Conde de Cominges. Drama en cinco actos. Traducido libremente del idioma italiano al espanol. Por Don Luciano Francisco Comella, s. 1., s. a., 27 págs. Hay también una versión manuscrita: Los amores del Conde de Cominges. Comedia en cinco actos. Primera parte. Por Don Luciano Francisco Comella, s. a. Censura de Fray Juan Antonio Peinado Gómez (14-XI-1796). Cf. FraNCisco Agullar PIÑal: Biblioteca de Autores Españoles del siglo XVIII. Tomo II, Madrid, C.S.I.C., 1983. Sólo he leído la primera edición que cito, a la que se refiere el análisis que sigue. ก̃olas.

20 a grafía del nombre de los personajes varía de una versión a otra en todas las obras espa- 
Com: No trunqueis esos acentos, cuyas voces mal formadas dan á mis ansias consuelo. Puedo esperar que me ameis? Me mata vuestro silencio.

Adel: Sino (sic) lo dicen mis labios mis ojos lo están diciendo.

Com: Como intérpretes del alma me declaran... Satisfecho de que su tierno lenguaje me descubra vuestro afecto, voy á verme con mi padre.

Adel: Lo que me cuesta dexaros! que no me olvideis os ruego.

Com: Yo olvidaros? Se conoce que ignorais que el amor mesmo os ha grabado en el alma con caracteres de fuego.

Añádase que en Los amores del Conde de Cominges se respeta la unidad de tiempo y lugar - que no la de acción, con tanto personaje innecesario que no hace más que entorpecerla-, con lo cual Comella constriñe la acción hasta convertirla en una mera anécdota, por no hablar de las muchas licencias que se ha tomado el autor español —o el italiano — con la trama de la historia original.

La comedia española resulta así cualquier cosa menos lo que es la primera parte de la novela francesa: la pintura de una pasión amorosa exaltada e irrenunciable. Es sólo una ocasión más para hablar de uno de los temas favoritos del teatro de estos años: el problema de los padres tíránicos que se oponen a la libertad y la felicidad de sus hijos. Pero todo ello plagado de tópicos y de actitudes y frases trilladas.

Eso sí, en esta desafortunada comedia puede leerse también una intención moralizadora, aunque muy debilitada con respecto a la versión de Bellosartes. Ernesto cierra la comedia con estas palabras: 
«No os quiere el ciélo dichosos,

según parece en la tierra;

os reservará otra dicha

que adquirireis con las penas,

trabajos, persecuciones,

que en segundo poema,

para ejemplo de los padres,

é instruccion de las solteras,

hará presente el ingenio.»

Algo más de interés ofrece la segunda parte de esta trilogía, compuesta por un desconocido N. N. y editada en Barcelona en 1820: Cominge perseguido ${ }^{21}$.

Esta vez el autor es bastante más fiel a la novela de la que extrae el argumento, aunque se permite también introducir algunos cambios. La comedia se centra en lo sucedido desde el encierro de Cominge en el castillo de su padre (acto I), hasta que se encamina a la Trapa (acto V). Los actos II a IV transcurren en casa de Adelayda ya casada, cerca de Burdeos, y dramatizan el encuentro de los amantes, su despedida, la pelea entre Benavides y Cominge y la huída de éste.

Vemos, para empezar, que el autor no ha acatado esta vez las unidades de tiempo y lugar - sí, en cambio, la de acción-. Esto le permite reflejar con mayor exactitud, y sin deformaciones, los acontecimientos de la novela y hacer menos forzada la adaptación de un texto narrativo a uno dramático, con las limitaciones que ello implica. Por otro lado, el autor parece ser bastante consciente de la dificultad de esa transferencia de géneros, y de las exigencias y características propias de cada uno, por lo que su versión acentúa los aspectos dramáticos y plásticos de las Mémoires ${ }^{22}$. También razones de dinámica

21 Cominge perseguido ó sea los amores del Conde de Cominge. Segunda parte. Drama original en cinco actos y en prosa, tomado el argumento de las Memorias de su vida, que escribió el mismo. Por N. N. Barcelona, Imprenta de José Tomer, 1820. Esta segunda parte es anunciada en la edición barcelonesa de 1820 de la traducción de Bellosartes, que por eso lleva el calificativo de "Tercera Parte». Sólo he encontrado ejemplar de esta versión en la Bibliothèque Nationale de París, $8 .^{\circ}$ Yf pièce 1045 . No tengo noticias de su representación, y dudo que la hubiera, dada la prohibición que pesaba sobre el drama de Bellosartes.

22 Véase, por ejemplo, la acotación que pone fin al acto III: «Cominge herido, es preso por los criados; Luisa socorre á su ama; Donville y Lorenzo al Conde, y Fabricio al Marques, de modo que formando un vistoso grupo cae el telon.» Y la liberación de Cominge por Orviñí sólo llega a los espectadores por el relato que hace Adelayda, único testigo de la escena: «Ya abre la puerta de la prision: Ya le llama: Cominge se presenta vacilante; se echa á sus pies... Oh Dios! Qué escena!» $(I V, 5)$. Por esta misma razón, sin duda, inventa el autor español una segunda despedida de los amantes (IV,7), que constituye el diálogo de mayor interés, argumental y dramático, entre ellos. 
teatral justifican la presencia de algunos personajes inexistentes en la novela - Luisa, criada y confidente de Adelayda, Fabricio, criado de Benavides-o el mayor papel concedido a otros - Donville, el carcelero de Cominge, su amigo Lorenzo--.

Lo que más sorprende en esta nueva versión de los amores frustrados de Cominge y Adelayda es la naturaleza de las innovaciones. El espíritu de este drama, con ser casi idénticos los hechros, traiciona bastante el de la novela francesa.

Los protagonistas siguen siendo los amantes apasionados que reivindican su libertad, pero el dolor desgarrado, la característica esencial de la obra de Tencin, parece aquí haberse atenuado, 0 , al menos, reducido a frases y actitudes que dejan una sensación de frialdad. El Comminge que escribía sus memorias tiene en este drama un reflejo menos firme, menos contundente en esa fuerza interior que le caracteriza de la primera a la última página de la novela. Este Cominge es más vehemente, más exaltado — sus celos de Orviñí, por ejemplo, son un matiz muy magnificado-, pero a la vez más débil; jura amor eterno a su amada, pero sólo le hace falta escuchar a lo lejos la campana de la Trapa para confesar su culpa y «delincuente, criminal y perseguido», «correr à los pies del altar sacrosanto, à borrar con las lagrimas del mas sincero arrepentimiento los estravíos (sic) de mi incauta juventud» $(\mathrm{V}, 3)$.

Y esta Adelăyda, todavía consumida por el fuego de la pasión en la parte correspondiente de la novela, salvo un arranque de sentimiento en el acto segundo ( Su amor!... En este instante.... el me consume... el me devora», II,4), es en todo el drama un alma contrita autoinculpándose y reconociendo su error: «Un amor culpable y criminal! (...) Hija inobediente, amante perjura, esposa desleal (...) No hay perdón para tantos delitos.» (II,1), «yo no puede resistir mas á los remordimientos que me devoran.» (IV,2), «Sí, Cominge: ya veis el abismo en el que este criminal amor nos ha sumergido.» (IV,7).

Pero no deja de resultar curioso que el rechazo de la pasión, puesto esta vez en boca del monje Gerónimo, no apele a la virtud o a la moral para convencer de sus nefastas consecuencias, sino a la voz de la razón:

Permitid que repreenda (sic) vuestro delirio. Ya no os hallais en edad de ceder de esta manera á los falsos atractivos de las pasiones, que arrastran al hombre (si no procura reprimirlas), á una ruina cierta y evidente. Vuestra erudicion y vuestro talento, la fuerza sobrenatural de la razon contra ellos, son bastantes para contener sus impulsos; sosegaos, querido Cominge... Oid la voz de la razon, y triunfareis. $(V, 1)$. 
Otro cambio sustancial se ha operado en la figura del padre. Éste del drama ejerce también su autoridad para separar a los amantes, pero su actitud tiene aquí una justificación:

Hijo mio, escuchame un instante, y despues decide si verdaderamente me intereso por tu felicidad. Cuando una pasion amorosa llega á apoderarse del corazon causa en el tan funestos estragos, que es preciso toda la prudencia del padre, para reprimir los ímpetus violentos de su furor. (...) asi yo severo é inflexible, te encerré en esta cárcel (...) y no me lastimó tu destino, porque conocí que á la pena sucedería la enmienda y el reconocimiento de ti mismo. He pasado á tus ojos por tirano, no lo dudo, pero el tiempo y la esperiencia (sic) te harán ver que todas mis acciones han sido hijas de la mas refinada prudencia. $(I, 4)$.

La trilogía dramática sobre los amantes desgraciados se cerraba con el drama de Bellosartes, que, como hemos visto, se reeditó en 1820 con ocasión de la salida de Cominge perseguido. Pero hay otra versión de esta tercera parte, Los amantes desgraciados o el Conde de Cominge ${ }^{23}$, realizada por Don José Pablo Muñoz de Camarena, de la que sólo se conserva ejemplar manuscrito, e igualmente traducción del drama de Baculard d'Arnaud.

La razón de que no llegara a editarse es comprensible: en 1801 había sido prohibido el drama de Bellosartes, y esta nueva versión se arriesgaba a tener la misma suerte. De hecho, el propio Muñoz de Camarena hace referencia a esta circunstancia al confesar los motivos que le llevaron a hacer su traducción, que es, por tanto, posterior a 1801:

Apliqueme al principio a su traduccion en el idioma castellano por juguete de la pluma: pero despues a instancias de los amigos me empeñe en concluirla. (...) No disimularè que si la tragedia de Cominge hubiera de representarse, deberia ser escrita a lo menos en asonantes, por que los Actores de $\overline{\text { nros }}$ teatros no pueden sugetarse a tomar de memoria, ni son capaces de darle el sentido que corresponde a los versos sueltos: pero Cominge no puede salir a la Escena, ni su santo instituto le permite âblar (sic) en publico ni en secreto sin licencia de su Padre Abad. (hojas 7 y 10).

23 Nuevo Drama d tragedia Yntitulada Los amantes desgraciados $O$ el Conde de Cominge. Escrito en frances por Mons. Arnaldo y traducido del frances al Español por el Licdo. Dn Josef Pablo Muñoz de Camarena. BN. Ms. 16327 
La versión de Muñoz de Camarena, en endecasílabos sueltos, es también muy fiel al drama original, con la salvedad de algunas modificaciones debidas, sin duda, el hecho de que esta traducción no está destinada a la representación. Así, el autor español suprime muy considerablemente las acotaciones e indicaciones escénicas y detalles del decorado, y procede en alguna ocasión a una división escénica diferente a la del original. Menos literal también que la versión de Bellosartes, la que él ofrece gana no sólo en corrección lingüística, sino también en calidad literaria. El espíritu, en cambio, sigue siendo el mismo y el contenido moral de la historia no se ha atenuado en nada. ${ }^{24}$.

Cuatro diferentes versiones dramáticas se hicieron en español de la historia de Comminge y Adélaïde ${ }^{25}$. En todas ellas se condenaba la pasión y se pintaban sus devastadoras consecuencias, pero el público español sólo la vio una vez en los escenarios. Pesaba sobre el mito una censura, y todavía, casi cien años después de su aparición, seguían sin conocerse sus orígenes, la novela de $\mathbf{M}^{\mathrm{me}}$ de Tencin.

\section{LA NOVELA Y EL POEMA}

Con una prohibición de representar la versión española del drama de Baculard -que describía con todo detalle los efectos de la pasión amorosa, cierto, pero que lo hacía para condenarlos enérgicamente- no era muy probable que la novela de $\mathbf{M}^{\mathrm{me}}$ de Tencin corriera mejor suerte. En ella la lección moral era tan débil que casi había que leerla entre líneas en las últimas páginas, y lo que

24 El drama va precedido de un «Prefacio al Letton» (hh. 2-11), una «Ydea del Ynstituto de la Trapa» (hh. 12-18) y las «Memorias del Conde de Cominge» (hh. 12-18). El prefacio es prácticamente una traducción el «Discours Préliminaire» de Baculard, con algunas reflexiones adicionales de Muñoz de Camarena sobre principios generales de la poesía. En cuanto a la historia de la Trapa, era un apéndice que se añadía con frecuencia a las ediciones francesas que reunían la novela, el drama y el poema. Su inclusión en esta versión española me hace pensar que el traductor manejó una edición francesa que inclúa todas esas composiciones. Lo confirmarían sus «Memorias del Conde de Cominge», resumen de la novela de $\mathbf{M}^{\mathrm{me}}$ de Tencin mucho más amplio y detallado que el «Extracto» que acompañaba el drama de Bellosartes, y que llega a reproducir textualmente frases enteras de la novela francesa.

${ }^{25}$ Moratín (Catálogo de piezas dramáticas publicadas en España desde el principio del siglo XVIII, en Obras de don Nicolás y Don Leandro Fernández de Moratín, Madrid, BAE, II, 1944, pág. 334) habla de una versión de Francisco Altés y Gurena: El Conde de Cominges, de la que no encuentro rastro. 
allí destacaba era precisamente lo que se quería condenar: la exaltación del amor, de la libertad y del individuo.

Malos tiempos corrían entonces en España para esas explosiones de libertad. El absolutismo fernandino imponía el exilio o el silencio. Y Comminge y Adélaïde de Lussan tuvieron que cruzar otra vez los Pirineos para poder expresar sus sentimientos.

En 1828 se publicaba, por fin, una traducción de la novela de $\mathbf{M}^{\mathrm{me}}$ de Tencin. En París. Anónima y exiliada: las Memorias del Conde de Comminge ${ }^{26}$.

La traducción es completamente fiel al texto original. Nada ha sido alterado, suprimido o añadido, si no es un adjetivo aquí o una coma allá. El traductor, ajeno a condicionamientos morales, quería transmitir el mito, la historia del amor desgraciado, tal cual fue concebido. Y Comminge y Adelaida hablan, ahora en español y con igual intensidad, de su pasión, de su dolor, de su exigencia de libertad. Pero esas voces no podían aún oírse en España.

En 1836, muerto ya Fernando VII, y el sentir romántico libre para expresarse en las letras españolas, pueden editarse en España las memorias de Comminge escritas en francés cien años antes.

La Historia del Conde Comminge ${ }^{27}$ reúne en un mismo volumen las memorias de $\mathbf{M}^{\text {me }}$ de Tencin, el drama de Baculard y el poema de Dorat.

El editor de la obra, que confiesa haber leído en su infancia la carta de Dorat, manifiesta su entusiasmo por haber encontrado por fin las tres «piezas» de la historia,

que es lo que doy á luz, y feliz la época en que he podido reunirlos y publicarlos, pues con el gobierno absoluto que lo tenia prohibido todo, no hubiere sido facil rendir este homenage á las almas sensibles, que no podrán menos de derramar lágrimas al leer la historia de estos amantes verdaderamente desgraciados. (s.p.)

26 Memorias del Cde. de Comminge. Novela escrita por Me. Tencin. Traducida al castellano. París, Librería Americana, 1828, 199 págs. Bibliothèque Nationale de Paris: Y2 71135.

27 Historia del Conde de Comminge seguida de una carta del Conde á su Madre, y un drama en tres actos. Adornada con una lámina. Barcelona: Librería de D. Manuel Saurí, 1836. El volumen comprende la «Historia del Conde de Cominge» (págs. [7]-125), la «Carta del Conde de Comminge a su madre. Por el célebre Dorat» (págs. [127]-152), «El Conde de Comminge. Drama en tres actos: Escrito en Frances por Mr. d'Arnaud, y traducido al castellano, por D. Manuel Bellosartes» (págs. [153]-228) y unas «Notas del traductor [a la carta]» (págs. 229-236). Se hizo una segunda edición en 1837. Cf. José F. MonTESINOS: Introducción a una historia de la novela en España en el siglo XIX, Madrid, Castalia, 1980, 4." ed., pág. 253. 
Pero hay algo alarmante en sus palabras. A renglón seguido leemos:

Ojalá que su lectura sea una leccion para los padres, librandolos de la preocupacion, y un freno á los jóvenes de ambos sexos para sugetar sus pasiones. Leed, pues, la historia de Cominge (sic) y Adelaida, y aprended.

La historia de los amantes desgraciados se presenta, por fin completa en España, desfigurada y arrastrando, en 1836, la rémora de unos códigos morales plenamente dieciochescos.

La traducción de la novela, anónima, como la del poema, es prácticamente la misma que la editada en París en 1828. Hay pequeñas variantes sin importancia, pero no cabe ninguna duda de que este segundo traductor tuvo delante la edición de París y la siguí fielmente ${ }^{28}$. Esto quiere decir que no es aquí donde se deformó la historia original de Comminge. La novela de $\mathbf{M}^{\mathrm{me}}$ de Tencin fue en español siempre fiel al contenido y al espíritu de lo escrito por su autora.

El drama que puede leerse en esta edición completa es el de Bellosartes, sin ninguna modificación, pero la traducción del poema de Dorat es la primera que aparece en español. Y aquí sí se produjeron importantes cambios, que requerirían un análisis más detallado del que los límites de este trabajo de conjunto imponen. A grandes rasgos, pues, esto es lo que ofrece esta traducción en endecasílabos con asonancia en los versos pares.

Para empezar, los cuatrocientos versos del original han sido casi doblados. Ello implica, de entrada, importantes amplificaciones y adiciones, pero sólo me detendré en dos. Por un lado, el dolor de la muerte, que era la nota dominante del poema francés, está aquí más acentuado si cabe. El poeta español, no con-

${ }^{28} \mathrm{Me}$ atrevo incluso a asegurar que este segundo traductor no vio el original francés, y sólo procedió a algunas modificaciones de estilo de la primera versión española. Ciertos detalles parecen confirmar esta hipótesis: por ejemplo, ambas traducciones agrupan en uno solo los diversos párrafos originales de los diálogos. Llama también la atención la idéntica traducción, muy peculiar, de algunos términos o pasajes: «une femme bien faite» = «muy buena moza», *belle fille $=$ «divina criatura», «une fatalité dont il n'est pas le maître» = «una fatalidad que le ha sido imposible poder prever ni evitar», «la fièvre me prit avec beaucoup de violence» = «una calentura sumamente fuerte se apoderó de min. Las pocas líneas añadidas al original, no más de diez, en la edición de 1828 lo son también en la de 1836, y lo mismo sucede con las mínimas supresiones. Las escasas variantes son casi siempre, como decía, correcciones de estilo o de lengua: «estábais amado» (1828)/ «érais amado» (1836), «el temor de disgustarla me retenia (contenia, 1836) siempre». 
forme con reconocer que la muerte le ha arrebatado su mayor bien dirige, con una furia acrecentada, sus increpaciones contra ella:

Pero ¡ó furiosa muerte! ¿quien tus pasos
hácia el templo de amor ha dirigido?
¿Quien tu funesta y bárbara guadaña
hácia mi bien supremo ha conducido?
¿Que te pudo traer á estos albergues
impenetrables aun del mismo viento?
¿Quien te pudo mandar que arrebatases
á mi Adelaida, que por siempre ha huido
de entre mis brazos tiernos y amorosos (...)?

(págs. 144-145).

Por otro lado, el Comminge del poema español muestra una rebelión mucho mayor contra la tiranía de su padre, que se extiende ahora hacia el «fementido mundo" y sus normas. Aquí y allá alarga o añade el poema las acusaciones al padre de ser el culpable de su desdicha:

¿Tu fuiste mi verdugo?... El mas impio de todos los verdugos, el mas fiero de cuantos hombres en el mundo ha habido.

(pág. 142)

Mis lágrimas veinte años han corrido, llorando las angustias que tu rabia, tu rabia insana y tu furor impío sembraron en mi amor.

(pág. 150)

¿Pero de penas tantas cual el origen es? ¿cual el motivo? La bárbara violencia de mi padre... ... preocupaciones de tan necio siglo... ¡El honor, la igualdad... todo fue causa de tales consecuencias!... Fementido mundo, mundo engañoso... 
Las numerosas modificaciones con respecto al poema original no alteran, sin embargo, su tono exaltado y, me atrevo a escribir ya con más propiedad, romántico. Pero un detalle modifica radicalmente el contenido y la intención de esta traducción: nueve «notas del traductor», de cuyo espíritu pueden dar cuenta estas líneas:

Muchos de estos ejemplos eran necesarios para destruir en cierto modo la corrupción de nuestro siglo, y plantificar (sic) la religion, bastante extinguida entre la perversa y malvada juventud que abunda.

(Nota 7, pág. 234)

¿Qué preciosa pintura para esos jóvenes corrompidos y criminales, cuya existencia no es mas que una serie de feroces crímenes; $y$ terribles consecuencias de estos! ¡Ah! si yo pudiera atraer la verdad á sus corazones y disipar las densas nieblas de su ignorancia con estos breves rengloncitos! iQuien mas feliz que yo! entonces si, entonces quedaria satisfecho enteramente de mi trabajo, y me vanagloriaria una y mil veces de mi empresa, al paso que despreciaria las nécias é insulsas sátiras que contra mí fuesen dirigidas.

(Nota 9, págs. 235-236)

El anotador no desaprovecha ocasión para hablar de las excelencias de la religión (nota 8), para sentenciar que el primer deber de los hijos es obedecer a sus padres (nota 2), o, sobre todo, para condenar con los más violentos adjetivos la pecaminosa pasión de los jóvenes.

Este exaltado defensor de tan morales reglas de conducta está traicionando en lo más profundo un texto literario utilizándolo para transmitir un mensaje que no es el que su autor original le dio. $\mathrm{Y}$ he escrito más arriba el anotador, porque me cuesta trabajo hacer responsable al traductor de esas notas. Le hubiera resultado más sencillo alterar de raíz el poema francés, hacer, por ejemplo, de Comminge, un paradigma del arrepentimiento que confesara sus «crímenes» y fuera un modelo para los «jóvenes descarriados».

Me inclino a pensar, más bien, que el autor de esas notas es el editor ${ }^{29}$, cuya intención moralizadora al publicar la historia completa del Conde de

29 Mis sospechas se basan además en otro detalle. En la versión española del poema, es el padre de Comminge quien encierra a Adelaida en el castillo. En la nota 3, el «traductor» señala que ese encierro fue dictado por el marido de la joven, y achaca el error a Dorat. Si el autor de la nota 
Comminge quedó manifiesta en la nota inicial. Si mi interpretación es acertada, resultaría así que en 1826, en plena explosión del Romanticismo en nuestro país, un editor logra reunir las tres piezas que componen la pintura de un amor imposible. La historia y los personajes son ya conocidos en España, y además, encajan perfectamente con las nuevas corrientes literarias que exaltan la libertad, hablan de la pasión y se recrean en ambientes lúgubres. Pero ese editor no comulga del todo con estos principios y propone una lectura diferente de los textos. Y esta Historia del Conde de Comminge, que tanto tardó en llegar completa a España, no es la exaltación de la pasión y la pintura del «dolor romántico» que hubiera debido ser en estos años. Por obra de unas notas, es un texto moralizante que intenta inducir a la virtud describiendo los estragos del vicio.

La Marquesa de Tencin escribió en 1735 una historia que proponía ya actitudes y sentimientos románicos; Baculard d'Arnaud la revistió en 1764 de la moralidad propia del siglo de las luces y Dorat, al mismo tiempo, le devolvió el primitivo espíritu de reivindicación del derecho a elegir, aunque fuera el dolor. A España llegó tarde, fragmentada y casi siempre desfigurada, y cuando por fin llegó completa fue para proponer códigos morales de una época ya pasada. No fue aplaudida en los teatros y hubo que cruzar fronteras para leerla, pero fue tan famosa a éste como a aquel lado de los Pirineos. Por ello, y a pesar de tantas trabas y deformaciones, fuera cual fuera su lectura y la intención que cada cual quisiera darle, el Conde de Comminge y Adélaïde de Lussan quedarán para la historia de la literatura como uno de los mejores modelos que creó el siglo XVIII del eterno mito de los amantes desgraciados.

hubiera sido el traductor, sabría perfectamente que Dorat no comete tal error en su poema, puesto que tenía el texto francés para comprobarlo. El error es, pues, del traductor, y la enmienda que aparece en la nota es, claramente, de otra mano. Por otro lado, si el autor de las notas fuera el traductor, ¿por qué hablar de «estos breves rengloncitos» (nota 9, cit. en el texto), después de haber escrito 778 versos? 